\title{
Memórias dos professores-artistas de dança: experiências de seus primeiros passos e suas ressonâncias
}

\author{
Memories of teacher-artists of dance: experiences of their first steps \\ and their resonances
}

\section{Memorias de los profesores-artistas de danza: experiencias de sus primeros pasos y sus resonancias}

\author{
Mariana Lopes Junqueira' \\ Centro Universitário Leonardo Da Uinci, Professora. \\ https://orcid.org/0000-0002-0155-8116 \\ Marco Aurelio da Cruz Souza ${ }^{2}$ \\ Universidade Regional de Blumenau, Professor. \\ https://orcid.org/0000-0002-9243-5372

\section{Carla Carualho ${ }^{3}$} \\ Universidade Regional de Blumenau, Programa de Pós-Graduação em Educação, \\ Professora. \\ https://orcid.org/0000-0002-1402-7920
}

Resumo: Ao ingressar no curso de Dança - Licenciatura, o acadêmico já possui uma trajetória com a Dança anterior ao curso e, por vezes, chega no ensino superior já atuando como docente em ambientes não formais de ensino. Este estudo teve como objetivo analisar experiências dos acadêmicos em sua trajetória na Dança e suas ressonâncias enquanto docentes. Os dados foram gerados por meio de um trabalho de uma disciplina do curso de Dança - Licenciatura, de uma universidade localizada no Sul do País, no qual 18 acadêmicos registraram suas memórias sobre suas aulas de dança enquanto estudantes no ensino não formal. Ao escrever e refletir sobre sua própria trajetória na Dança, os acadêmicos conseguem identificar ressonâncias dessas experiências enquanto docentes. Utilizamos como aporte teórico autores que abordam a experiência (LARROSA, 2016), as pedagogias no ensino da dança (STINSON, 1995) e as narrativas utilizadas em percursos de formação (JOSSO, 2007). Os relatos sinalizam que a maioria dos acadêmicos tiveram suas primeiras vivências em dança em espaços não

Mestre em Educação pela Universidade Regional de Blumenau; doutoranda em Educação pela Universidade do Estado de Santa Catarina

2 Doutor em Motricidade Humana, especialidade de Dança, pela Universidade Técnica de Lisboa, Portugal; Mestre em Performance Artística, Dança, pela Universidade Técnica de Lisboa, Portugal.

3 Doutora em Educação pela Universidade Federal do Paraná; Mestre em Educação pela Universidade do Vale do Itajaí. 
formais ou informais de ensino e que a dança está pouco presente na Educação Básica, até mesmo como forma de nutrição estética. Os acadêmicos indicam dilemas das aulas de dança, como aulas em espaços inadequados, a pouca presença de meninos nas aulas, o preconceito e a utilização da metodologia tradicional, mesmo em diferentes espaços de ensino e estilos de dança. Alguns registros apontam vivências em aulas baseadas nas pedagogias crítica, criativa e feminista, sinalizando uma mudança de pensamento sobre a Dança no seu cotidiano docente.

Palavras-chave: Docência em Dança. Experiência. Metodologias do ensino da dança.

Abstract: The dance student when entering the course of Dance - "Licenciatura-degree", he already has a trajectory with the dance before the course, and sometimes arrives in the higher education already acting like professor in non formal environments of education. This study aims to analyze the experiences of dance's students in higher education in their dance career and their resonances as teachers. The data were generated through a work of a discipline of the Dance course - Licenciatura, from a university located in the south of Brazil, in which 18 dance's students recorded their memories about their Dance classes as students. In process of writing and reflecting on their own trajectory in Dance, academics can identify resonances of these experiences as teachers. We use as a theoretical contribution authors that approach the experience (LARROSA, 2016), pedagogies in dance teaching (STINSON, 1995) and the narratives used in training courses (JOSSO, 2007). The reports indicate that most of the academics had their first experiences in Dance, in non-formal or informal spaces of teaching, and that Dance is little present in Basic Education, even as a form of aesthetic nutrition. Academics indicate dilemmas of dance classes, such as classes that happened in inadequate spaces, the lack of presence of boys in class and the prejudice of it, and the excessive use of the traditional pedagogy even in different teaching spaces and dance styles. Some records point out experiences in classes based on critical, creative and feminist pedagogies, signaling a change of thought about Dance in its daily teaching. Keywords: Teaching in dance. Experience. Methodologies of dance teaching.

Resumen: Al ingresar em El curso de Danza - "Licenciatura", El acadêmico ya tiene uma trayectoria con la danza anterior AL curso, ya muchas veces está actuando como docente em ambientes no formales de enseñanza. Este artículo tiene como objetivo analizar experiências de lós acadêmicos em su trayectoria em La Danza y SUS resonancias como docentes. Los datos fueron generados por médio de um trabajo de uma disciplina Del curso de Danza - Licenciatura, de uma universidad ubicada em El sur de Brasil, em La cual 18 académicos registraron sus memórias sobre sus clases de Danza como estudiantes. Al escribir y reflexionar sobre su propia trayectoria em La Danza, lós acadêmicos logram identificar resonancias de esas experiências como docentes. Utilizamos como aporte teórico autores que abordan la experiência (LARROSA, 2016), las pedagogias en la enseñanza de la danza (STINSON, 1995) y las narrativas utilizadas em itinerários de formación (JOSSO, 2007). Los relatos señalan que la mayoria de lós acadêmicos tuvieron sus primeras vivencias em Danza, en espacios no formales o informales de enseñanza, y que la Danza está poço presente em la Educación Básica en el sur de Brasil, incluso como forma de nutrición estética. Los académicos indican dilemas de las clases 
de Danza, como clases en espácios inadecuados, la poca presencia de niños en las clases y el preconcepto, y la utilización de la pedagogia tradicional incluso en diferentes espacios de enseñanza y estilos de danza. Algunos registros apuntan vivencias em clases baseadas em las pedagogias crítica, creativa y feminista, señalando un cambio de pensamiento sobre la Danza en su cotidiano docente.

Palabras clave: Docencia en danza. La experiência. Metodologia de la enseñanza de la danza.

Recebido em 11 de outubro de 2019 Aceito em 11 de março de 2020

Publicado em 23 de julho de 2020

\section{AS AULAS ACONTECIAM NESTA ORDEM, ALONGAMENTO...}

"0 corpo é um dos elementos essenciais da dança, nesse sentido se faz necessário ter o cuidado e consciência sobre ele, conhecê-lo bem." (informação verbal). Antes de iniciar uma atividade que vai lidar diretamente com o corpo, como normalmente acontece nas aulas de dança, é importante prepará-lo fisiologicamente, o que geralmente se faz com alongamentos ou exercícios de warm up. Da mesma forma como, ao iniciar uma pesquisa, é importante preparar o leitor para o que virá adiante, contextualizar o tema escolhido. A frase escolhida para iniciar este estudo é de uma acadêmica do Curso de Dança - Licenciatura de uma Universidade localizada no Sul do Brasil, utilizada para descrever as memórias de seus primeiros passos na Dança.

Atualmente, o ensino de Dança pode ocorrer em espaços formais, não formais e informais de ensino, conforme Terra (2010) nos apresenta:

0 artista da dança se produz no intercruzamento dos diferentes espaços de formação, informação, criação e difusão onde ocorrem estudos, pesquisas, experiências e práticas estético-artísticas as quais deverão ser constantemente problematizadas, contextualizadas em suas dimensões estéticas, culturais, educacionais, sociais, econômicas e políticas. (TERRA, 2010, p. 75).

A formação em Dança em espaços formais de ensino pode ocorrer por meio de cursos de licenciatura, bacharelado e tecnólogo em Instituições de Ensino Superior (IES) e por meio de cursos oferecidos em escolas credenciadas pelo Ministério da Educação (MEC), que concedem diplomas e certificados de formação (curso técnico profissionalizante). A formação em espaços não formais é obtida por meio de cursos livres oferecidos por academias, estúdios, projetos sociais e centros culturais, que não concedem o diploma reconhecido pelo 
MEC (UNIVERSIDADE REGIONAL DE BLUMENAU, 2017). A formação em espaços informais se realiza no próprio meio de convivência do sujeito, como o ambiente familiar, por exemplo.

A aprovação da Lei n. 13.278/2016 inclui as Artes Visuais, a Dança, a Música e $\circ$ Teatro como as linguagens que constituem o componente curricular Arte, obrigatório na Educação Básica (BRASIL, 2016). Assim, os sistemas de ensino possuem cinco anos, da aprovação da lei, para promover a formação de professores e implantar esses componentes curriculares na Educação Básica. Nesse sentido, faz-se necessária a discussão sobre a formação desses professores, que poderão suprir essa necessidade e lacuna de ensino de dança na Educação Básica ou em outros espaços. Atualmente outros documentos nacionais que discutem a Educação Básica também acenam a dança como componente curricular, é o caso da Base Nacional Comum Curricular, que, aprovada no ano de 2018, afirma a dança como componente curricular na área das linguagens (MINISTÉRIO DA EDUCAÇÃO, 2018).

Quando os(as) artistas que se formam em escolas técnicas de dança se tornam professores(as), por vezes, acabam reproduzindo em suas aulas o que receberam durante o seu percurso de formação. Monte (2003) pesquisou a formação e atuação dos professores de dança na Cidade de Florianópolis, SC, demonstrando a tendência destes em reproduzir os ensinamentos aprendidos com seus mestres. 0 estudo ainda mostra que essa disposição ocorre nos elementos reunidos na formação de bailarinos clássicos: padrão físico, tendências pedagógicas, práticas e ensinamentos teóricos, com propensão a excluir os alunos que não se encaixam nos modelos. Dessa forma, faz-se necessário refletir sobre a formação desses professores, assim como a dos que são formados em cursos superiores de IES.

Este estudo tem por objetivo analisar experiências dos acadêmicos em sua trajetória na Dança e suas ressonâncias ${ }^{4}$ enquanto docentes. Esta pesquisa foi realizada com acadêmicos do curso de Dança - Licenciatura de uma universidade da região Sul do País. Buscando conhecer a história na Dança vivida por cada um deles, os dados foram gerados por meio de um trabalho desenvolvido na disciplina de Metodologia do Ensino da Dança Escolar, que ocorre no terceiro semestre do curso. Nessa disciplina foi realizada uma atividade na qual eles deveriam descrever suas memórias enquanto estudantes de dança em formação ocorrida em espaços formais, não formais ou informais, dialogando com as metodologias estudadas na disciplina. Participaram deste estudo 18 acadêmicos que já possuíam experiência com a Dança anterior ao curso, sendo que $100 \%$ deles já atuavam como docentes antes de ingressar no Ensino Superior. 
0 curso de Dança na IES na qual a pesquisa foi realizada visa formar um professor/artista/pesquisador oferecendo uma formação técnica, estética, artística, sensível, teórica, criativa e pedagógica ao futuro professor de Dança (UNIVERSIDADE REGIONAL DE BLUMENAU, 2017), o que difere de uma formação apenas com foco em técnicas sistematizadas de dança. Essa primeira seção apresentou a temática, assim como o objetivo deste estudo. A segunda seção vai apresentar o referencial teórico que sustenta esta pesquisa, a terceira seção trará à baila os relatos dos acadêmicos e as análises, e a quarta seção vai abordar as considerações finais.

\section{EXECUÇÃO DE PASSOS DA COREOGRAFIA...}

Figuras 1 - Acadêmicos do Curso de Licenciatura em Dança em exercícios cênicos

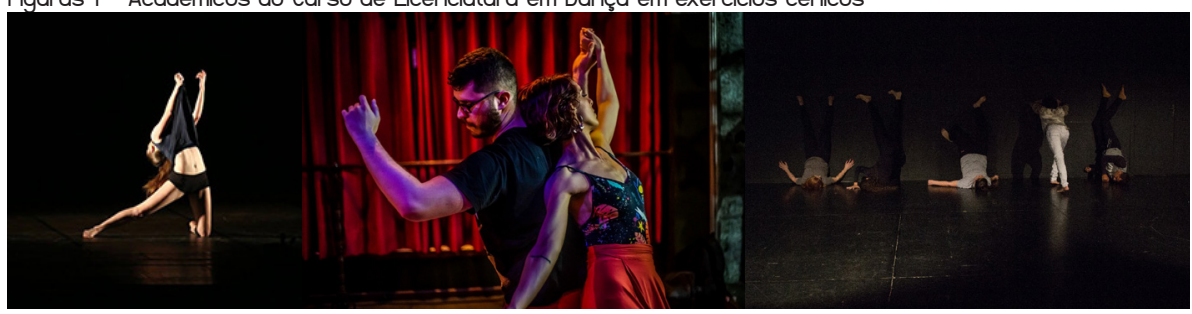

Fonte: os autores.

"Execução de passos da coreografia [...]" (informação verbal). Tornar-se, sentir-se bailarino. Eis a questão que nos move a compreender a ressonância desse processo na formação do estudante de dança numa licenciatura, que, por vezes, é marcada por suas experiências em contextos completamente diferenciados do contexto escolar.

As imagens que abrem esta seção nos fazem pensar sobre esse lugar de aprender dança e compreender-se bailarino e logo na sequência compreender-se professor de dança na relação com quem dança, com o contexto em que se dança e na relação com os estudantes. A continuação da frase da acadêmica descreve o restante da aula de dança, mas esse não é o registro de apenas uma aula, mas de todas as aulas realizadas pela acadêmica em um determinado espaço durante sua formação em Dança fora da universidade. 0 mais preocupante é que esse registro se repete nas memórias de todos os acadêmicos participantes da pesquisa, mesmo que suas experiências com a Dança tenham acontecido em espaços de ensino diferentes e em diferentes modalidades de dança. Parece até uma receita de como deve acontecer uma aula de dança. Mas será que existe um modelo para 
uma boa aula de dança para todas as idades, públicos e modalidades? ${ }^{5}$ Todos devem seguir esse roteiro pré-estabelecido de aula?

\begin{abstract}
No processo de formação de bailarinos(as), as práticas corporais não devem ser realizadas única e exclusivamente de forma mecânica e sem a participação do(a) bailarino(a), pois desta forma estaria limitando a criatividade do(a) mesmo(a). A matriz curricular dos cursos de dança seja ele livre, técnico e ou de graduação devem oferecer componentes que oportunizem os(as) mesmos(as) a poderem interpretar o mundo e propor movimentações próprias que podem auxiliar em seu processo de autonomia e transformação individual. (UNIVERSIDADE REGIONAL DE BLUMENAU, 2017, p. 20, 21).
\end{abstract}

0 Curso de Licenciatura em Dança da IES investigada tem a preocupação de trazer um novo olhar para a formação dos futuros professores-artistas-pesquisadores de Dança, para que não reproduzam o que, na sua grande maioria, aprenderam nas aulas de dança em ambientes não formais de ensino, a partir de um único método, conhecido como método tradicional de ensino. ${ }^{6}$ Nesse sentido, nesse curso há o pensamento voltado para a conscientização e o respeito ao corpo e ao processo criativo e para a participação dos alunos durante a aula de dança, uma vez que o curso

\footnotetext{
[...] se propõe a romper com o modelo tradicional de formação em dança, pautado no condicionamento do corpo baseado nos princípios renascentistas de dança clássica, preparando o estudante para o espetáculo e com conteúdos pré-concebidos. Terá como foco a riqueza das danças populares e contemporâneas e de suas possibilidades criativas do movimento no ato educacional. (UNIVERSIDADE REGIONALD E BLUMENAU, 2017, p. 32).
}

Assim, enquanto o acadêmico "se percebe artista em seu processo de criação, também se percebe professor em formação, discutindo especificidades da linguagem da dança." (UNIVERSIDADE REGIONAL DE BLUMENAU, 2017, p. 32). Uma vez que o curso tem o seu PPC voltado para uma reflexão dos professores-artistas de Dança, faz-se necessário que cada acadêmico retorne às suas memórias enquanto aluno e reflita sobre a sua formação.

Stinson (1995) escreve sobre suas experiências com as diferentes pedagogias da Dança classificando-as em: pedagogia tradicional, pedagogia crítica, pedagogia da dança criativa e pedagogia feminista. Para a autora, na pedagogia tradicional 
[...] o professor é a autoridade e a única fonte de conhecimento reconhecida. Todos alunos olham para o professor e para o espelho e o professor frequentemente olha para o espelho também, vendo os alunos através de suas imagens refletidas. Não existe interação entre os alunos. Espera-se que a voz do professor seja a única voz ouvida, exceto em casos de perguntas dirigidas a alunos espećíicos. 0 professor diz e mostra aos alunos o quê e, em alguns casos, como fazer os exercícios propostos. Alunos tentam copiar o movimento feito pelo professor. 0 professor, então corrige-os verbalmente, os alunos repetem o movimento até a hora de mudar de sequência. (STINSON, 1995, p. 78,79).

Na pedagogia tradicional, o professor trabalha numa perspectiva do ensino diretivo, demonstra os passos, enquanto os alunos os realizam e o professor corrige. Não há espaço para a voz do aluno e para o processo de criação. 0 professor é o detentor do conhecimento e já traz os exercícios da aula e os movimentos da coreografia a ser ensaiada pronta, conforme já indicavam Sööt e Viskus (2014) em seus estudos. Sampaio e Almeida (2009, p. 18) dizem que as escolas tradicionais que trabalham com foco na reprodução de movimentos

[...] surgem com a função básica de inserção no mercado de trabalho, sempre vinculando essa formação a uma determinada tarefa ou posto de trabalho sem haver preocupação com a formação teórica que era passada aos alunos. A preocupação primária dessas escolas era com o saber fazer.

A pedagogia crítica, por sua vez, surgiu como uma alternativa para as pedagogias tradicionais, "esta pedagogia tem suas raízes na teoria crítica social que clama por justiça social e econômica, assim como por mudanças fundamentais em como vemos as qualidades dos indivíduos." (STINSON, 1995, p. 81). A pedagogia crítica se baseia em diálogo crítico e racional com os alunos, o que, para a autora, possui algumas implicações, como, por exemplo, para utilizá-la com crianças precisa-se ter o cuidado para que todas as vozes sejam ouvidas.

A pedagogia da dança criativa incentiva a autoexpressão e a resolução de problemas, e parte da ideia de que "todos podem dançar"; nesse sentido, a dança criativa utiliza o "movimento natural" no lugar de formas estilísticas idealizadas. Na pedagogia criativa o professor é compreensivo e carinhoso (STINSON, 1995).

Na pedagogia feminista o aluno é encorajado a ouvir seu próprio corpo, ao invés de olhar para o professor ou para sua própria imagem no espelho. Na pedagogia feminista há espaço para discussão e reflexão, assim como para a criação de movimentos. Stinson (1995, p. 85) afirma, baseada em suas experiências: 


\begin{abstract}
Acredito que os sentimentos dos alunos são tão importantes quanto suas idéias e seus movimentos, assim como tentar abrir espaço para reconhecer estes sentimentos em pequenos grupos, discussões com toda a classe ou em diários (guardados individualmente ou trocados com parceiros de confiança como um diálogo escrito). Fazendo perguntas para discussão ou trocando diários, professores podem também conectar-se com assuntos que possam estar surgindo na sala de aula (tal como sexismo, homofobia, fobia por gordura) e suas relações com o espaço fora da sala de aula. (STINSON, 1995, p. 85).
\end{abstract}

Para Stinson (1995), o professor não pode se ater apenas a assuntos relacionados à técnica ou a uma estética de dança, mas precisa estar aberto para ouvir os alunos e abrir espaço para discussão de outros assuntos que estão surgindo entre os alunos.

Este estudo tem o olhar voltado para a experiência dos acadêmicos sobre o ensino de Dança, uma vez que, para Larrosa (2016), experiência é o que nos passa, nos acontece, nos toca e nos transforma. Assim, "o sujeito da experiência seria algo como um território de passagem, algo como uma superficie sensivel que aquilo que nos acontece afeta de algum modo, produz alguns afetos, inscreve algumas marcas, deixa alguns vestígios, alguns efeitos." (LARROSA, 2016, p. 25). A experiência, para Larrosa (2016), é única, singular e não pode ser repetida ou reproduzida; nesse sentido, uma pessoa não pode impor sua experiência a outra pessoa. Duas pessoas podem passar por um mesmo acontecimento e terem experiências diferentes.

[...] a experiência é o que me acontece e o que, ao me acontecer, me forma ou me transforma, me constitui, me faz como sou, marca minha maneira de ser, configura minha pessoa e minha personalidade. Por isso, o sujeito da formação não é o sujeito da educação ou da aprendizagem e sim o sujeito da experiência: a experiência é a que forma, a que nos faz como somos, a que transforma o que somos e o que converte em outra coisa. (LARROSA, 2016, p. 48).

Para analisar as experiências que os acadêmicos tiveram com o ensino de dança, foi solicitado que eles registrassem suas memórias por meio de um texto autobiográfico, narrando suas histórias enquanto estudantes de dança. Esses registros poderiam conter fotos para ilustrar os diferentes momentos que a memória foi capaz de tocar. Para Josso (2007, p. 413), “as narrações centradas na formação ao longo da vida revelam formas e sentidos múltiplos de existencialidade singular-plural, criativa e inventiva do pensar, do agir e do viver junto." Para a autora, ao se trabalhar com pesquisas a partir da narração de histórias de vida, é possível "estabelecer a medida das mutações sociais e culturais nas vidas singulares e relacioná-las com a evolução dos contextos de vida profissional e social." (JOSSO, 2007, p. 414). 
A autora aborda que o conhecimento de si mesmo pelas transformações do ser, do que a pessoa viveu, suas atividades, seus acontecimentos pessoais e sociais é o que gera a construção da identidade (JOSSO, 2007).

\footnotetext{
A história de vida é, assim, uma mediação do conhecimento de si em sua existencialidade, que oferece à reflexão de seu autor oportunidades de tomada de consciência sobre diferentes registros de expressão e de representações de si, assim como sobre as dinâmicas que orientam sua formação. (JOSSO, 2007, p. 419).
}

Como foi abordado anteriormente, ao ingressar no curso de Dança, os acadêmicos já tiveram experiências anteriores com a Dança, e essas experiências influenciam na sua constituição como professor-artista, assim, é importante olhar para essas narrativas para compreender essa composição. Olhamos esses dados provocados pela condição de atuação profissional desses estudantes de um curso de licenciatura: todos já atuam como professores de dança em espaços não formais de ensino. Dessa forma, para adentrarmos nas histórias de cada acadêmico por meio de suas falas, substituímos seus nomes reais por nomes de grandes personalidades da dança no Ocidente, para que possamos nos familiarizar e dançar com eles.

\section{DEPOIS, EXECUTAR COM A MÚSICA}

Depois de realizar o alongamento, executar os passos da aula e da coreografia, chega o momento de executar os passos aprendidos com a música, e assim encerra a aula, sem espaços para a realização de processos criativos e para que a voz do aluno seja ouvida. Realidade que se repete na história de diversos acadêmicos. Parece até que todos frequentaram a mesma aula, o mesmo espaço formativo. Felizmente podemos observar alguns relatos que apontam para mudanças nas aulas de dança após iniciarem o Curso de Licenciatura em Dança na IES pesquisada.

Nos relatos dos acadêmicos podemos observar quais foram os seus primeiros passos na Dança. Os dados sinalizam que alguns dos acadêmicos tiveram suas primeiras experiências em dança em espaços não formais de ensino, como escolas de dança, estúdios de dança e academias de dança, como segue nos relatos a seguir: 
paquitas. [...] Comecei a fazer aulas na associação da empresa onde meu pai trabalhava, eles ofereciam várias atividades [...] e uma delas era aula de dança, muito conhecida hoje como Baby Class (Fuller).

A dança esteve mais presente na minha vida de forma não formal, ao participar de pequenos grupos infantis que, em sua maioria, não se atinham a técnicas de modalidades específicas. (Pavlova).

0 primeiro contato impactante com a dança foi quando tinha três anos de idade, fui matriculada nas aulas de ballet [...] (Bausch).

Comecei na dança quando eu tinha apenas 4 anos, por influência da minha prima [...] que sempre dançou também. Sempre olhava ela dançar, e achava lindo, e sempre pedia para minha mãe me colocar na escola de dança. Então ela me colocou, e assim comecei a dançar na academia [...], na modalidade Jazz, em algumas aulas fazíamos ballet. (Botafogo).

Entrei na dança aos $\Pi$ anos no programa de dança [...]. A modalidade era o Jazz. (Graham) (informações verbais).

Brown (2018) aborda em suas memórias que "Meu primeiro ano da dança foi em 2007, pela Fundação [...] (informação verbal).

Alguns relatos sinalizam que poucos acadêmicos tiveram o seu primeiro contato com a dança no ambiente escolar, em aulas que aconteciam no contraturno: “Com 7 anos de idade, fui matriculada em uma turma de ballet clássico na escola onde estudava [...]" (Vaganova). Rainer (2018) traz em seu relato: “Comecei a fazer aula de dança no ano de 2006, na Escola de Educação Básica [...]. Eu estava na $1{ }^{a}$ Série do Ensino Fundamental I e estava muito empolgada para o início da aula de dança." (informações verbais).

Apenas um acadêmico relatou que as aulas aconteceram no turno regular em sua Escola, "[...] aos 11 anos, em uma escola na cidade vizinha [...], surgiu a oportunidade de participar de uma competição escolar de dança, [...] iniciamos nossos ensaios nas aulas de educação física [...]" (Limon, informação verbal).

Esse relato sinaliza que o ensino de dança ainda está presente nas aulas de educação física, e não como uma das linguagens da Arte, o que para a época ainda era comum, visto que havia um pequeno número de cursos superiores de Dança no Brasil. Essa formação ocorria em disciplinas isoladas nos cursos de graduação em educação física ou teatro, sendo tratada como conteúdo, e não como área de conhecimento.

Os relatos dos acadêmicos sinalizam o quão frágil é a presença da dança nas escolas de Educação Básica no Estado de Santa Catarina, uma vez que poucos deles relataram que sua primeira experiência com a Dança foi nesse ambiente. 0 que nos chama a atenção é que nenhum comentou, por exemplo, que assistiu uma apresentação de dança 
que foi oportunizada pela escola, o que demonstra que não há nem mesmo o espaço para a nutrição e a fruição estética dessa linguagem na escola.

A maior parte dos acadêmicos relata que seu primeiro contato com a dança foi em espaços informais de ensino, geralmente no ambiente familiar:

Na minha história, partindo dos gostos da minha mãe, sempre tive a dança presente, seja pelos passinhos das discos dos anos 80 ou nas danças de salão que ela sempre comentava. (Shay).

Cresci ao som de músicas alemãs tradicionais, da rádio AM que a minha avó paterna sintonizava. Ela sempre foi muito festeira e para comemorar seus aniversários fazia uma grande festança, [.... Festa com direito a almoços e jantares e muita música ao vivo. [...] Neste ambiente familiar que se situam as primeiras experiências com dança que me recordo. Eu por ser criança, não participava, mas trago a lembrança de que eram dias em que todos dançavam e se divertiam muito. (Laban).

Estas memórias me transportam para o contexto familiar, onde as festinhas na casa de minha familia eram bastante frequentes. Eu e minha prima [..., nos divertíamos ao som de uma música animada, sem nos preocupar com o tipo de movimentação ou estética alguma, e nossos parentes nos observavam felizes e orgulhosos. Deviamos ter entre seis e sete anos, imagino. (Asteire).

As primeiras memórias de dança que tenho são das festas de final de ano na casa de meus avós [...], em que a familia se reunia sempre regada de muita música, o que nos fazia remexer desde crianças. Seja em uma dança solta com os irmãos e primos ou a dois, apoiando-me nos pés de meu pai, esperava ansiosamente por esses momentos. (Kerche).

Nessas ocasiões festivas, a minha familia, muito ampliada pela presença da vizinhança, reunia-se para fazer grandes e inesqueciveis confraternizações. Meu pai me conduzia pela mão e, muito desajeitado, ensaiava passos de algo que somente ele julgava ser de alguma dança. (Nijinska).

Já nasci ouvindo muita música com meus pais, e logo estava dançando pela casa, com três anos minha brincadeira preferida era dançar ao som de músicas clássicas que pedia para meu pai tocar e me vestia com figurinos improvisados e adereços da minha mãe, lenços. (Duncan).

A dança sempre esteve presente nas reuniões da familia dos meus avós maternos, uma família numerosa, que se encontrava sempre nos finais de semana [...]. Qualquer encontro de familia virava cantoria (todos tocavam algum instrumento, cantavam, e até as crianças tinham sua vez, tendo como instrumento duas colheres) e consequentemente a dança despontava. (Wigman) (informações verbais).

Nesse primeiro contato com a Dança em espaços informais de ensino, os relatos indicam que os acadêmicos tiveram experiências que os marcaram em momentos 
de descontração familiar, mas que eram momentos em que não havia uma preocupação com o fazer artístico. Eram momentos em que era permitido criar seus próprios passos e dançar livremente. Alguns dos acadêmicos relatam, ainda, que só tiveram consciência da importância desse primeiro contato com a dança quando ingressaram no curso de licenciatura e discutiram nas aulas sobre os diferentes espaços de ensino. Os relatos indicam que as primeiras vivências dos acadêmicos em Dança, em sua grande maioria, ocorreram em espaços não formais ou informais de ensino.

Esses acadêmicos, ao registrarem suas memórias, apontam que mudaram de contexto de ensino de Dança, passando por algumas escolas e diferentes grupos, mas nesses primeiros registros podemos identificar como foram seus primeiros passos. Ao relatarem como seguiram a trajetória na Dança, alguns acadêmicos afirmaram que em algum momento a dança se fez presente na escola.

Eu já frequentava a escola, na qual havia apresentações de quadrithas, cacetinhos, cirandas e outras danças. Participava de algumas com muito entusiasmo, aprendendo os passos (coreografias) de cada uma" (Nijinska).

Já no ensino médio, meus amigos criaram um grupo chamado Elite Step. As aulas aconteciam no ginásio da escola l...] no contra turno das aulas. (Laban) (informações verbais).

Pavlova, em suas memórias, registra: "No ensino formal, apesar das aulas de Artes - lecionadas pela minha irmã - por vezes colocarem a dança em pauta [...]" (informação verbal).

Mesmo com esses poucos registros da dança no espaço escolar, no decorrer da trajetória dos acadêmicos, percebe-se que ainda são poucas as iniciativas de trazer a dança para dentro da escola, quase que sendo negligenciada. Verifica-se que as escolas não oportunizam aos estudantes o acesso a práticas poéticas e expressivas na Dança, legitimando-a enquanto área de conhecimento e como uma das linguagens artísticas. Nesse sentido, a maioria dos acadêmicos relata suas vivências em outros espaços de ensino. 


\subsection{DILEMAS DAS AULAS DE DANÇA}

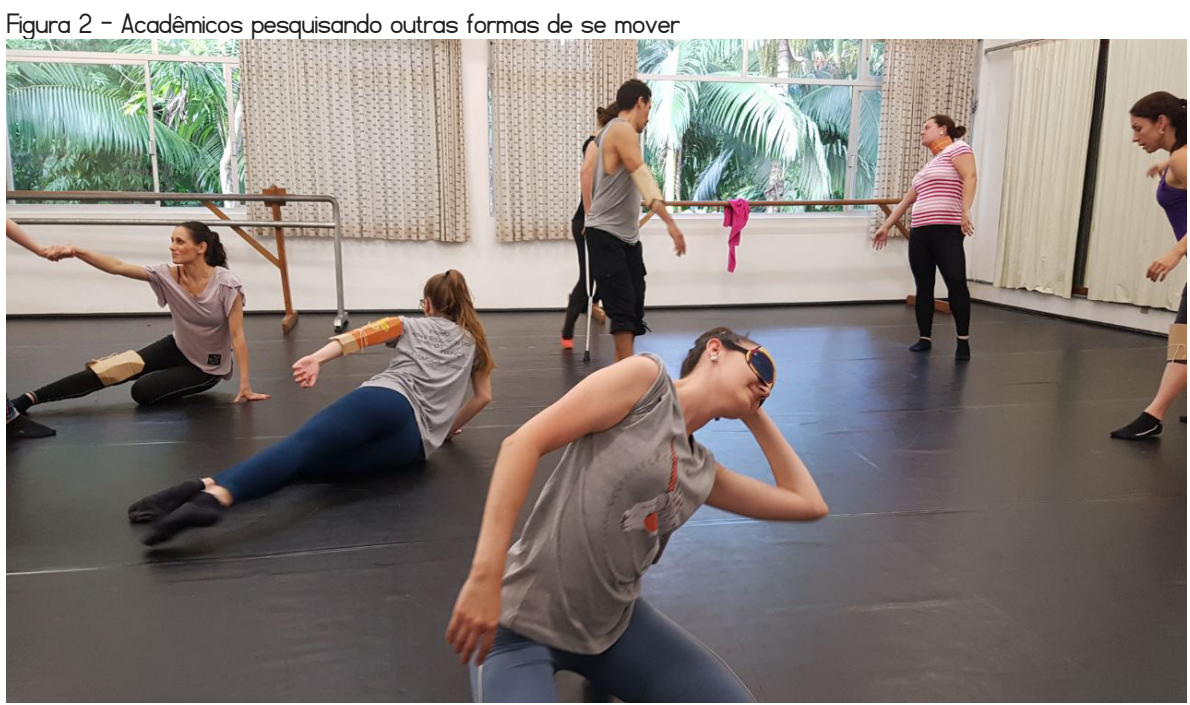

Fonte: os autores.

Tentamos compreender como esses acadêmicos se sentem diante das aulas que vivenciaram nas suas vidas de bailarinos e das aulas que vivenciam na universidade. Percebemos aqui uma intencionalidade de focar numa prática que os desloque do contexto da repetição de passos, da busca pelo movimento uníssono, da competitividade, da dança enquanto rendimento. Nesse percurso, a imagem que abre essa sessão pode ser um indicador que nos mobiliza a refletir e relacionar os corpos e sua subjetividade a partir do que viveram e, por vezes, do que vivem, em paralelo ao curso de licenciatura.

Nos registros dos acadêmicos podemos identificar o quão importantes e marcantes foram os seus primeiros contatos com a Dança, que refletiram em suas trajetórias. Mas esses registros apontam alguns dilemas sobre as aulas de dança. Identificamos pelos relatos dos acadêmicos que muitas das aulas aconteciam sempre em uma mesma sequência, na qual o professor passava o alongamento, ensinava os passos para os alunos, que repetiam e assim treinavam a coreografia já montada pelo professor. 0 aluno não tinha voz durante a aula, e por vezes eram realizadas atividades que podiam prejudicar o corpo dos alunos em busca de um "corpo ideal" para determinada performance, pois não eram adequadas para aquela faixa etária ou técnica trabalhada. Por meio dessas práticas que se tornavam excludentes, podemos dizer que os corpos dos alunos eram tratados como objetos, e a dança era entendida apenas como um conjunto de movimentos anátomo-psico-sócio-cinesiológico. Isso 
é um grande erro, pois a dança deve ser tratada e entendida como "um objeto passível de apreciação estética e artística" (GEHRES, 2008, p. 22), consistindo num meio de expressão e criatividade para além das técnicas corporais fechadas.

Acreditamos que o professor não fazia isso de propósito, mas apenas reproduzia a experiência que ele próprio teve em sua formação. A repetição de passos também ocorre pelo ensino ser voltado a apresentações de final de ano, eventos ou competições de dança, assim a aula gira em torno do ensaio para que essa apresentação aconteça de forma uníssona. Como identificamos nos relatos dos acadêmicos:

0 professor fazia vários exercícios conosco, tínhamos colchonetes, e ele utilizava para fazer os alongamentos e alguns exercícios de força. Hoje vejo que ele fez muitos exercícios que não eram próprios para a minha idade e de outras meninas que estavam lá. Poderíamos ter nos machucado e forçado o nosso corpo, pois não tínhamos uma consciência corporal desenvolvida. (Rainer).

Quando chegávamos para a aula e ainda acontecia a aula anterior, [...] não podíamos atrapalhar a aula acontecendo, não podiamos conversar, não podíamos brincar, podíamos somente ficar sentadas observando a aula acontecendo (Graham).

Para não dizer que nunca tivemos dança na escola, teve uma vez que fui chamada para dar aula de dança no contraturno das aulas, para duas turmas de meninas com idades de 7 a 9 anos. Eu tinha 15 anos, como era muito nova, uma professora de artes me acompanhava nas aulas. Eu dava aulas no mesmo jeito que aprendi, sequências, diagonais e técnica. (Botafogo) (informações verbais).

Mesmo que a primeira experiência dos acadêmicos não tenha sido nesses moldes da pedagogia tradicional, em algum momento eles relatam que passaram por alguma aula assim:

Nas aulas tínhamos dois momentos: o primeiro, que aconteciam os ensaios de prática, no segundo, os ensaios de coreografias de apresentações. (Alonso).

No início da aula fazíamos os alongamentos, que mais parecia um método de tortura, tudo para ter o espacate perfeito, pois as alunas do núcleo central eram obrigadas a fazer espacate. No primeiro ano não havia nas aulas o favoritismo, mas não podiam faltar as alunas que faziam de tudo para ficar na frente, bajular a professora era o método campeão. (Graham). 
Em relação à metodologia de ensino, encontrei na dança de salão também a presença marcante da pedagogia tradicional, onde, naquela época ao menos, homens conduziam e mulheres eram conduzidas. (Kerche).

0 Professor explica, demonstra e corrige exercícios, sendo autoridade máxima e a única fonte de conhecimento. Os alunos apenas aprendem a reproduzir o que recebem e não a criticar e criar arte, dança, movimentos... Sentimentos e emoções são reprimidos, a interação não existe ou é suprimida é há uma certa hierarquia e competição entre os alunos. Além do que, o corpo é visto como objeto a ser julgado, e valoriza-se que seja esbelto e comprido - um grande problema e, talvez, motivo das maiores frustrações na dança para mim. (Pavlova).

Uma frase que me marcou nos ensaios da coreografia da aula de ponta foi "sorriam, bailarina não sente dor". (Graham) (informações verbais).

Os relatos sinalizam como a pedagogia tradicional se fazia presente, além de não ter espaço para que o aluno fosse ouvido ou para que processos de criação fossem desenvolvidos. Havia a risada do professor constrangendo o aluno quando ele errava um passo. Os alunos precisavam bajular a professora para ter um lugar mais à frente na sala. Não era permitido brincar numa perspectiva de pesquisa, apenas obedecer e ter disciplina. Não era permitido sentir dor, não importando o quanto era exigido do corpo que, por vezes, nem estava preparado. Havia um modelo ideal de corpo, que era o magro e longilíneo. Geralmente quando pensamos em tradicionalismo em dança, pensamos no ballet, mas os relatos sinalizam que em diferentes modalidades de dança, como o jazz ou a dança de salão, a pedagogia tradicional de ensino da dança se fazia presente. Além do predomínio da pedagogia tradicional, os acadêmicos relatam o preconceito com os meninos na aula de dança:

Passaram algumas aulas de dança e na escola regular, um dia, na aula de uma professora, ela resolveu fazer perguntas para os alunos, o que cada um teria feito no final de semana. Eu estava na terceira carteira mais ou menos e fiquei nervoso pensando se falaria ou não das aulas de dança que eu estava fazendo, já estando na segunda falando, eu ainda não sabia se iria compartilhar o meu final de semana com medo se ser motivo de chacota por toda turma, quando o colega da frente estava no discurso final pensei comigo mesmo que não falaria das aulas de dança, mas foi tão no automático que não pensei para falar, e por impulso falei sobre as aulas de dança que eu fazia durante os sábados, por menos de cinco segundos, por ouvir a palavra dança a sala inteira começou a rir, e dali partiram para a agressão verbal, me chamaram de muitas e muitas coisas até a professora intervir e colocando-os em seus devidos lugares. Em seguida ela deu um sermão em todos aqueles que estavam fazendo as chacotas, falando que a dança era feita por homens, sim, e tinha que ser muito homem para fazer dança. (Joss, informação verbal). 
Joss ainda relata que havia o estranhamento das colegas de aula e dos pais delas: "Chegando lá as meninas estranharam logo de cara um menino entre elas, não estavam acostumadas a ver meninos além dos pais delas quando iam buscá-las no final das aulas." (informação verbal).

Até mesmo as acadêmicas sinalizam a falta de meninos durante a aula: "Era uma turma de meninas, não eram proibidos meninos, mas não havia uma procura por parte deles." (Graham). Rainer recorda que "a turma era muito grande, inteiramente constituída por meninas com faixa etária de seis a dez anos." (informações verbais).

Apenas um acadêmico relatou a presença de meninos na aula de dança: "[...] todos os meninos da sala que estudava toparam participar, [...] onde uma professora de dança [...] foi nos apresentada e dada a missão a ela de ensinar cerca de 12 meninos, sendo que a maioria nunca fez alguma aula na vida, ou até mesmo dançou." (Limon, informação verbal).

Os registros dos acadêmicos sinalizam, ainda, o preconceito em relação aos homens na dança, espaço ainda ocupado em sua grande maioria por mulheres. Tanto as dançarinas quanto aqueles que estudam com os dançarinos estranham a presença de dançarinos nas aulas. Isso mostra o quanto ainda se tem a visão de que a dança é para as meninas.

Outro dilema apontado por uma acadêmica acontece em muitas famílias, quando os pais querem que os filhos participem da mesma atividade, não respeitando a individualidade e o gosto de cada um: "[...] fui matriculada nas aulas de ballet em São Paulo (SP), na qual fiquei seis meses, pois minha irmã não se adaptou, e foi o motivo da minha saída. Além de ser um desrespeito a minha individualidade." (Bausch, informação verbal).

Além disso, há relatos que indicam a falta de preparo dos espaços que recebem os alunos para as aulas de dança, nesse sentido professores e alunos precisam se adequar a espaços impróprios para que as aulas aconteçam: "[...] as aulas eram realizadas em um espaço aonde acontecia eventos, festas de casamento, debutantes, entre outros." (Graham). Rainer relata que "Realizávamos as aulas no refeitório da escola, que era um espaço grande, porém era muito sujo." (informações verbais).

Nos relatos identificamos que as aulas, quando ocorriam nas escolas, aconteciam em espaços inadequados, utilizados para outros fins, ou seja, não havia estrutura necessária para receber a aula de Dança. 


\subsection{NOUOS MODOS DE PENSAR A AULA DE DANÇA}

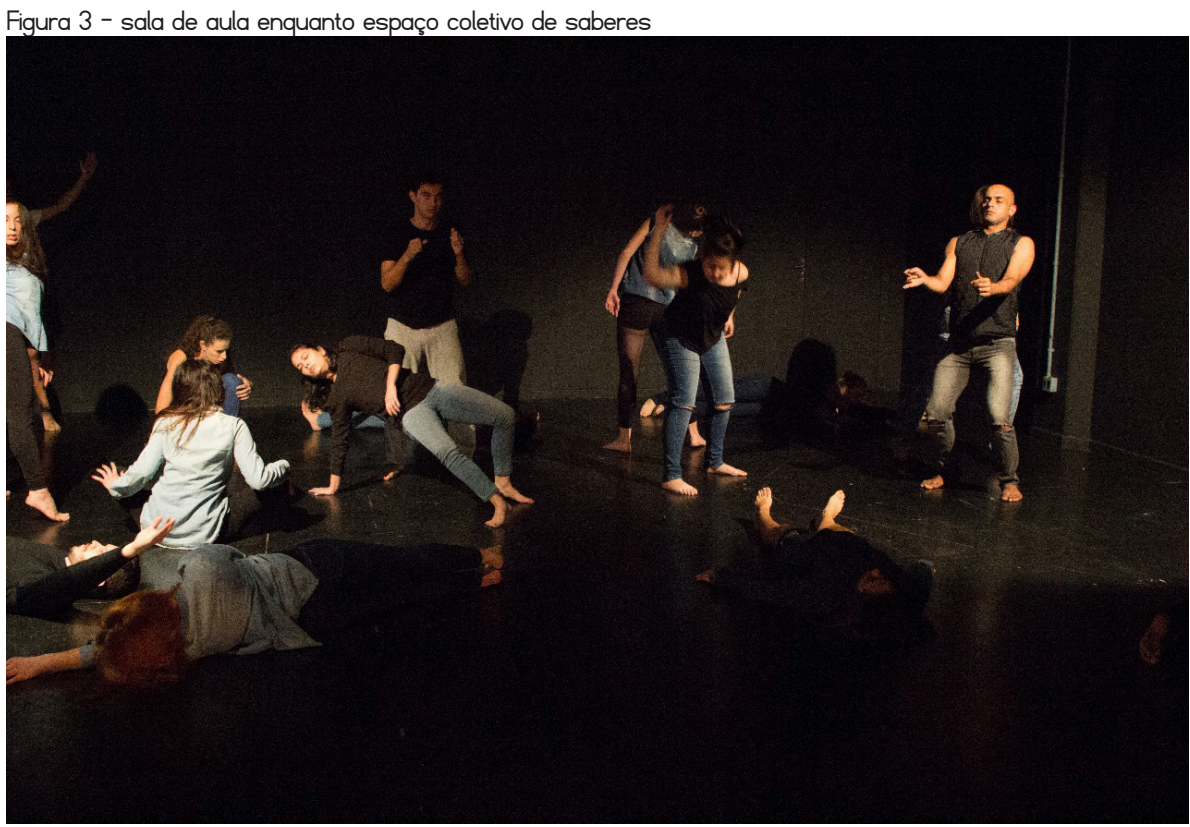

Fonte: os autores.

Apesar dos dilemas apontados pelos acadêmicos, movimentos vividos nas aulas os deslocaram a outros lugares de aprender e, por consequência, outros lugares de se constituírem professores de Dança. A imagem que abre esse subtexto nos provoca a pensar nesses possíveis lugares de aprender, de compartilhar saberes, nessas possíveis metodologias diferenciadas que surgem como fonte de liberação de sentido e de transformação pessoal e social. Stinson (1995) trata da noção de conscientização, compreensão e transformação da realidade de forma crítica, não aceitando o conformismo, o individualismo e o autoritarismo. Alguns relatos sinalizam que eles tiveram experiências de pedagogias críticas, criativas ou feministas:

As aulas eram bem dinâmicas e era assim que acontecia todos os dias, passávamos o dia inteiro experimentando coisas diferentes, diagonais, centro, e sempre que podia ela passava danças para que a gente pudesse colocar no nosso corpo algo diferente, sempre nos corrigindo, ensinando. [...] Já nas Danças Populares Brasileiras era o momento que tínhamos "livre", nos divertíamos com as danças, era o momento de nos livrar um pouco das aulas "quadradas" que tínhamos costume de fazer, o professor tinha dinâmicas e diferentes modos de dar a sua aula cada dia na semana, onde 
fazia com que a aula fosse uma pedagogia crítica. Faziamos coreografias que me deixavam me sentir uma outra pessoa. (Joss).

Depois de um longo período afastada da dança [... acabei indo fazer um workshop de dança contemporânea [...] no tempo que fiz dança nunca tinha feito nenhuma aula que fosse tão aberta onde eu podia usar o que meu corpo tinha sem seguir necessariamente um padrão. (Fuller) (informações verbais).

Kerche relembra que:

Em alguns momentos nos processos de dança contemporânea, dependendo do professor ou coreógrafo convidado, tínhamos chance de experimentar, de sugerir, de arriscar. Hoje compreendo que essas foram as melhores partes.

Foi literalmente o meu ano de transformação na dança e pessoal. Tive muitas dificuldades para conseguir dançar e me expressar na coreografia, tanto que o professor até dava um tempo e depois voltava para ver se eu me desenvolvia. Foi até o momento em que eu me descobri, e percebi que quando eu dançava eu me deslocava para um local totalmente distante, e ao mesmo tempo tão profundo em mim. (Raine) (informações verbais).

Em um primeiro momento, alguns acadêmicos sinalizam que não foi algo natural ter aula com outros tipos de pedagogia, uma vez que estavam formatados às aulas nos moldes tradicionais. Mas eles sinalizam o quanto essas aulas os marcaram, uma vez que tinham espaço para falar, opinar e criar. Essas aulas os fizeram sentir a liberdade, criar uma nova relação com o corpo, se perceber, experimentar, arriscar. 0 corpo já não é mais visto como um objeto. Passa a ser sujeito. 0 dançarino já não é mais compreendido apenas como um executor de passos. Ele é seu corpo.

Por vezes, essas pedagogias se manifestaram apenas quando os acadêmicos já estavam no curso de licenciatura em Dança e se tornaram docentes, movimento vivido na relação com a profissão e com a sua formação no ensino superior:

Em 2016 fui convidado pelo professor [...] a ser instrutor do projeto de extensão em danças de salão [...]. Este é sem dúvida um dos fatores mais importantes no meu desenvolvimento quanto professor de dança. Neste projeto pude experimentar diversas novas formas de trabalhar a dança de salão. [...] Os primeiros desafios surgiram quando o [..] coordenador do projeto, pediu para que trabalhássemos com métodos diferentes dos tradicionais. Defendendo que as escolas não formais já davam conta desta demanda tradicional e tínhamos que fazer diferente por estarmos dentro de uma universidade. (Laban). 
Hoje reconheço que levava a dança no método "ultratradicional", onde a liberdade era vedada e existia o certo e errado, mas ao decorrer dos anos minha visão foi mudando. (Limon) (informações verbais).

Ao se tornarem professores-artistas, os acadêmicos refletem sobre a sua prática e mudam a perspectiva de suas aulas de dança. Essa reflexão ocorreu por meio do que estão experimentando, pesquisando e estudando no curso superior em Dança, ou pelo incentivo de professores que já abandonaram a pedagogia tradicional e que provocaram esses docentes a pensarem de uma forma diferente, como foi o caso de Laban.

Nóvoa (1992), ao abordar a formação docente, indica que esta se relaciona com o desenvolvimento pessoal na relação de produzir a vida do professor. Nesse sentido, podemos perceber que os estudantes se percebem professores nesse movimento. Ainda, o autor acena que $\circ$ desenvolvimento profissional tem relação com o processo de produzir a profissão docente, assim observamos que se sentem em processo de produzir a profissão e nela se percebem sujeitos em transformação e ação. Com isso, acenam a relevância de tornar-se agente no processo, desde a relação com a técnica até o processo do desenvolvimento organizacional mais amplo, que significa o produzir a escola, fazer o contexto que se constitui nesse processo.

\section{EM BUSCA DOS ÚLTIMOS PASSOS: TENTATIUA DE TECER ALGUMAS CONSIDERAÇÕES FINAIS}

Figura 6 - 0cupação do espaço cênico como constituição docente

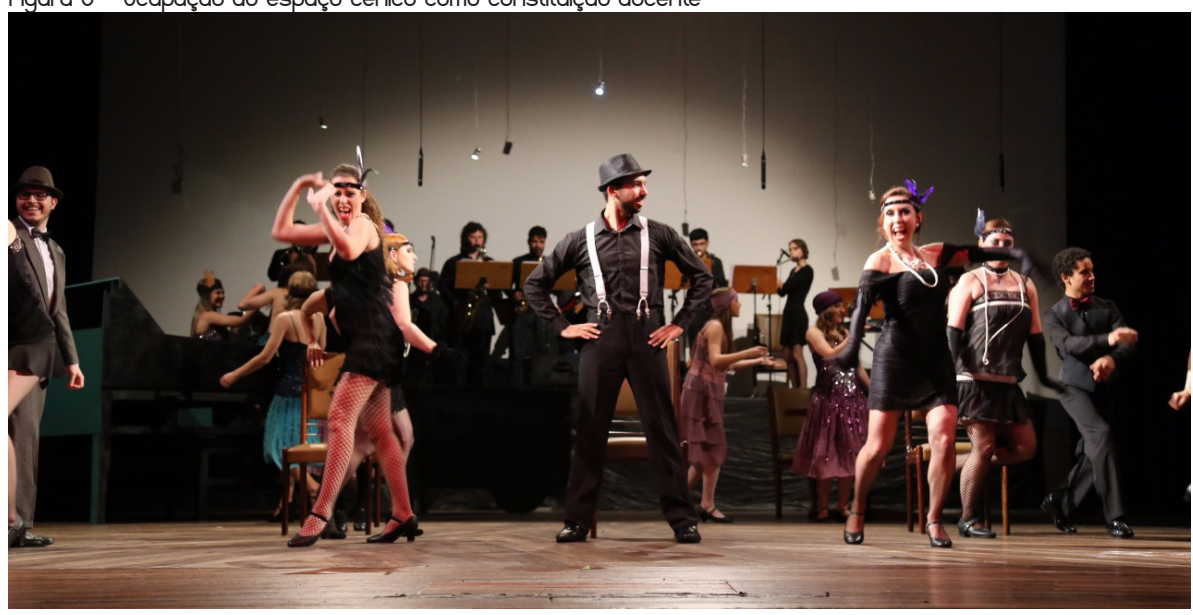

Fonte: os autores. 
São bailarinos e estão em processo de constituição da formação docente. A imagem que abre esta seção do nosso artigo nos leva a pensar sobre esse lugar que é o palco, lugar de arte que mobiliza nossos acadêmicos a sua formação inicial na Arte e agora na docência. Esse palco, esse lugar da poética é o lugar de encantamento, de encontro e de busca que os mobilizam a vir ao contexto acadêmico buscar formação para o encontro com a formação na licenciatura. Percebem-se professores-artistas em formação, no entanto vivenciam dilemas desses processos e lugares vividos antes da vida acadêmica.

Este estudo, que teve como objetivo analisar experiências dos acadêmicos em sua trajetória na Dança e suas ressonâncias enquanto docentes, levou-nos a pensar e sistematizar alguns indicadores acerca desse processo. Por meio de narrativas sobre suas memórias com o ensino de Dança, os acadêmicos refletiram sobre sua trajetória, tecendo um diálogo com o que estudaram na disciplina Metodologia do Ensino da Dança Escolar. Essas memórias sinalizam que a maioria dos acadêmicos tiveram suas primeiras vivências com a dança em espaços não formais ou informais de ensino. Nesse sentido, os dados apontam que a dança ainda está pouco presente nas escolas de Educação Básica, não somente pensando em seu ensino, mas como espaços de apreciação artística e estética de dança.

Os relatos sobre as primeiras vivências em espaços informais sinalizam que muitos dos acadêmicos tiveram essas experiências no convívio familiar e que se deram conta dessas vivências nas discussões realizadas na disciplina Metodologia do Ensino da Dança Escolar. Essas vivências em espaços informais acenam para experiências que marcaram os acadêmicos como momentos de alegria, descontração e liberdade, uma vez que no convívio familiar cada um tinha liberdade para criar seus passos de dança, ao invés de executar passos criados por outras pessoas, e que os impulsionaram a buscar aulas específicas de dança.

No ensino de Dança em espaços não formais ou na escola de Educação Básica, os acadêmicos indicam alguns dilemas, como a falta de espaço adequado para a aula de dança e a pouca participação de meninos, assim como o preconceito enfrentado pelos que participaram das aulas.

Apesar de os acadêmicos registrarem que participaram de aulas em diferentes espaços e realizaram aulas de diferentes modalidades de dança, os relatos das aulas se mostraram muito similares, como se as aulas de dança seguissem uma "receita". Em sua maioria, essas aulas seguiam a pedagogia tradicional, muitas vezes não por culpa dos professores, pois estes apenas estavam reproduzindo o ensino da maneira que aprenderam. Outra forma que leva à utilização da pedagogia tradicional é quando o espaço que oferece a aula se volta muito para apresentações, fazendo com que as aulas se tornem ensaios. Essas aulas deixaram marcas nos acadêmicos, uma vez que nelas eles não podiam falar, expressar 
opinião, brincar com seus corpos, ter liberdade expressiva. Essas aulas foram relembradas como momentos de exigir ao máximo do corpo dos alunos, um espaço da busca por corpos ideais para a dança, de grande competição entre os dançarinos e de corpos dóceis, que apenas executam os passos que o professor ensina sem questionamento.

Os relatos sinalizam que, apesar de todos terem alguma experiência com a pedagogia tradicional, que fez com que alguns quase desistissem da dança, alguns tiveram outras vivências, como estudantes ou como docentes, principalmente após ingressarem no Curso de Dança - Licenciatura. Nessas vivências, eles tiveram liberdade para falar, opinar, criar, sentir e conhecer o seu próprio corpo, o que, em um primeiro momento, não pareceu algo natural, uma vez que estavam acostumados com a pedagogia tradicional. Mas os acadêmicos relatam os momentos de liberdade e de profundo conhecimento de si nessas vivências.

Ao concluírem suas memórias, os acadêmicos descrevem que com as discussões e experimentações práticas sob novas perspectivas de ensino no Curso de Licenciatura em Dança, como docentes buscam trabalhar de forma diferente da pedagogia tradicional, com foco nos corpos de seus alunos e suas potencialidades. Nem sempre isso é possível, uma vez que em alguns lugares as apresentações de final de ano ainda são muito cobradas, mas eles relatam que em alguma parte da sua aula buscam oportunizar momentos de escape para a criatividade. Nesse sentido, espera-se uma presença efetiva da Dança na escola de Educação Básica nos próximos anos, e que essa presença não venha a ser carregada da perspectiva tradicional de ensino da dança, que condiciona os alunos apenas a reproduzirem passos, podando sua criatividade. Assim como se espera uma mudança nas aulas de dança em outros espaços de ensino, que não sejam voltadas apenas para apresentações de final de ano e que oportunizem aos estudantes bailarinos terem direito à voz, à criação e ao conhecimento do seu próprio corpo nas aulas de dança. Que as aulas possam fomentar as relações consigo, com os outros e com o mundo. Espera-se que, conforme sugere Marques (2007), a formação em dança nas escolas contemporâneas inicie-se com o desenvolvimento de um pensamento crítico e a sensibilidade estética e artística dos alunos. Isso distanciase da ideia de conhecimento transmissivo (tradicional), tão fortemente enraizado em muitos professores de dança. A escola deve ser vista enquanto espaço cultural que oportuniza uma parcela de tempo para a formação humanística e cultural.

0 desejo é que a dança na escola de Educação Básica surja como um projeto educacional que vise melhorar o processo formativo dos estudantes por meio da Dança em diferentes aspectos (emocional, criativo, pertencimento, cognitivo, relacional, social) para além do domínio de uma técnica sistematizada. Os professores de dança que irão atuar nesse projeto devem estar em constante reflexão sobre o contexto atual da sociedade e sobre suas práticas e atentos às necessidades reais de seus alunos. Entendemos que é uma nova possibilidade de educar. Educar por meio da Dança, de forma que se distancie do treinamento 
de padrões motores e da aquisição de conhecimentos já prontos. Estamos propondo que nas escolas haja um espaço maior para a valorização desse conhecimento artístico, permitindo aos estudantes a possibilidade de vivenciar diferentes processos criativos em dança a partir de seus saberes e sentidos personalizados.

Um grande começo é que, na formação inicial dos professores-artistas de Dança que participaram do estudo, esses temas venham à baila, para que possam ressoar em sua trajetória docente.

\section{REFERÊNCIAS}

BRASIL. Lei n. 13.278, de 2 de maio de 2016. Altera o $§ 6^{\circ}$ do art. 26 de da Lei n. 9.394, de 20 de dezembro de 1996, Lei de Diretrizes e Bases da Educação, referente ao ensino da arte. Diário Oficial da União: seção 1, Brasilia, DF, p. 1, 3 maio 2016.

GEHRES, A. F. Corpo-Dança-Educação: na contemporaneidade ou da construção de corpos fractais. Instituto Piaget, Lisboa. 2008.

HOUAISS, A.; VILLAR, M. de S. Dicionário Houaiss da língua portuguesa. Rio de Janeiro: Objetiva, 2009.

JOSSO, M. C. A transformação de si a partir da narração de histórias de vida. Educação, ano XXX, v. 3, n. 63 , p. $413-438$, set./dez. 2007.

LARROSA, J. Tremores: escritos sobre experiência. Tradução: Cristina Antunes e João Wanderley Geraldi. Belo Horizonte: Autêntica Editora, 2016.

MINISTÉRIO DA EDUCAÇÃO. Base Nacional Comum Curricular. Brasília, DF: MEC, 2018.

MARQUES, I. Dançando na escola. 2. ed. São Paulo: Cortez, 2007.

MONTE, F. C. de S. G. 0 processo de formação dos professores de dança de Florianópolis. 2003. 147 f. Dissertação (Mestrado em Educação Física) - Universidade Federal de Santa Catarina, Florianópolis, 2003.

NÓVOA, A. (coord). Os professores e a sua formação. Lisboa: Dom Quixote, 1992.

SAMPAIO. R. L; ALMEIDA. A. R. S. Da Escola de Aprendizes Artífices ao Instituto Federal da Bahia: uma visão histórica da educação profissional. In: FARTES, V. L. B.; MOREIRA, V. C. (org.). Cem anos de educação profissional no Brasil: história e memória do Instituto Federal da Bahia: (1909-2009). Salvador: EDUFBA, 2009.

SÖÖT, A.; VISKUS, E. Contemporary approaches to dance pedagogy - the challenges of the 21st century. Procedia - Social and Behavioral Sciences, v. 112, p. 290-299, 2014. 
SPOHN, C.; PRETTYMAN, S. S. Moving is like making out: developing female university dancers' ballet technique and expression through the use of metaphor. Research in Dance Education, v. 13, n. 1, p. 47-65, 2012.

STINSON, S. W. Uma pedagogia feminista para dança da criança. Pro-posições, v. 6, n. 3, p. 77-89, nov. 1995.

TERRA, A. Onde se produz o artista da dança? In: TOMAZZONI, A.; WOSNIAK, C.; MARINHO, N. Seminários de dança: algumas perguntas sobre dança educação. Joinville: Nova Letra, 2010.

UNIVERSIDADE REGIONAL DE BLUMENAU. Projeto Pedagógico do Curso de Dança - Licenciatura. Blumenau: FURB, 2017.

Endereço para correspondência: Rua Antônio da Veiga, 140, Itoupava Seca, Blumenau, Santa Catarina, Brasil; marcoaurelio.souzamarco@gmail.com

Roteiro, Joaçaba, U. 45, p. 1-24, jan./dez. 2020 | e21314 |E-ISSN 2177-6059 
